\title{
Properties of Concrete Incorporating Dolomite Powder
}

\author{
${ }^{1}$ L.Ranjith Kumar, ${ }^{2}$ J.Kiran, ${ }^{3}$ P.Rangarajan \\ ${ }^{1}$ Assistant Professor, Panimalar Engineering College, Chennai \\ ${ }^{2 \& 3}$ Student, Panimalar Engineering College, Chennai
}

\begin{abstract}
The purpose of this work is to describe the effect of fine ground dolomite on important physical and mechanical properties of concrete. Dolomite powder has some similar characteristics of cement. The replacement percentages tried were 0\%, 5\%,10\%, 15\% and 20\% by weight of cement. The compressive, split tensile and flexural strengths of concrete with dolomite powder were compared with those of the reference specimens. The results indicate that replacement of cement with dolomite powder increases the compressive, split tensile and flexural strengths of concrete.
\end{abstract}

Keywords: dolomite limestone; Portland cement; compressive strength.

\section{Introduction}

One of the major achievements of the cement and concrete industries during the past years is the increasing use of mineral additions. The high cost of energy, diminishing energy sources in the world and the greenhouse effect require that energy consumption be reduced by all industries. The benefits of addition of supplementary materials to Portland cement are well documented. Concrete is the basic civil engineering material used in most of the civil engineering structures. Many materials are used to manufacture good quality concrete. Cement is the most important constituent material, since it binds the aggregates and resists the atmospheric action. Since the production of Portland cement clinker is an energy-intensive process, a partial substitution of clinker by mineral additions obviously represents considerable energy savings. It makes economic sense to reduce the energy used in the production of cement and concrete and at the same time make a safe use of what sometimes can be classified as an industrial waste. Dolomite is a rock forming mineral which is noted for its remarkable wet ability and dispensability. Dolomite has a good weathering resistance. Dolomite is a preferred for construction material due to its higher surface hardness and density. Some investigations confirmed that finely ground dolomite can be used as cementitious material to produce cement with dolomite. An attempt has been made to explore the possibility of using dolomite as a replacement material for cement.

\section{Materials And Methods}

Cement is a binder, a substance that sets and hardens independently, and binds other materials together. Portland cement was used as the main binding material. To prepare a mix, gravel sand size up to $2.5 \mathrm{~mm}$ was used as an aggregate, in the ratio 3:1 with Portland cement.

Dolomite is a rock forming mineral which is noted for remarkable wet ability and dispensability as well as moderate oil and plasticizers absorption. Dolomite has good weathering resistance. Two kinds of dolomite fine powder with mean particle size $4 \mu \mathrm{m}$ and $2.79 \mu \mathrm{m}$ and specific surface $5500 \mathrm{~cm}^{2} / \mathrm{g}$ and $7523 \mathrm{~cm}^{2} / \mathrm{g}$, respectively, were examined. Mixtures containing finely dolomite from 0 to $20 \%$ by weight of cement were prepared. Water/binder ratio of control specimens was 0.5 . The most important function of the aggregate is to assist in producing workability and uniformity in mixture. River sand was used as fine aggregate. The specific gravity of sand was found to be 2.56 . The coarse aggregate is the largest component of concrete. Size of coarse aggregate used in the investigation was $10 \mathrm{~mm}$. The specific gravity of the coarse aggregate was found to be 2.68. Water is an important ingredient of concrete as it actively participates in the chemical reaction with cement. Water for making concrete should have $\mathrm{pH}$ between 6 and 8. Locally available drinking water was used in this work.

Table 1: Properties of Dolomite

\begin{tabular}{|c|l|l|}
\hline S.No & \multicolumn{1}{|c|}{ Property } & \multicolumn{1}{c|}{ Dolomite Powder } \\
\hline 1 & Sp. Gravity & 2.75 \\
\hline 2 & Colour & White \\
\hline 3 & Moisture & Nil \\
\hline 4 & Crystal System & Trigonal \\
\hline 5 & Sieve analysis & Zone III \\
\hline
\end{tabular}




\section{Compressive Strength}

\section{Test Results}

The cube compressive strength of concrete was determined by conducting test on $150 \mathrm{~mm} \times 150 \mathrm{~mm} \times$ $150 \mathrm{~mm}$ cube specimens at 7 days, 28 days of curing. After curing, three cube specimens were tested on a compression machine. The specimens were tested in the compression testing machine of $2000 \mathrm{kN}$ capacity. After keeping the specimens on the compression testing machine, the load was applied at a uniform rate of $140 \mathrm{~kg} / \mathrm{cm} 2 / \mathrm{min}$ until the failure of the specimen. The average value of the three results was taken as the compressive strength.

Table 2: Compressive Strength Result

\begin{tabular}{|c|c|c|c|}
\hline \multirow{2}{*}{ S.No } & \multirow{2}{*}{ \% Replacement } & \multicolumn{2}{|c|}{ Strength $\left(\mathbf{N} / \mathbf{m m}^{2}\right)$} \\
\cline { 3 - 4 } & & $\mathbf{7 ~ d a y}$ & $\mathbf{2 8}$ day \\
\hline 1 & 0 & 17.25 & 29.62 \\
\hline 2 & 5 & 19.26 & 31.35 \\
\hline 3 & 10 & 17.22 & 28.65 \\
\hline 4 & 15 & 16.64 & 24.63 \\
\hline
\end{tabular}

\section{Split Tensile Strength}

Tensile strength of concrete greatly affects the extent and size of cracking in concrete. Tensile strength of concrete is less when compared with its compressive strength. Cylinders of diameter $150 \mathrm{~mm}$ and height $300 \mathrm{~mm}$ were used to determine the split tensile strength. After curing, the specimens were tested on the compression testing machine.

Table 3: Split Tensile Strength Result

\begin{tabular}{|c|c|c|c|}
\hline \multirow{2}{*}{ S.No } & \multirow{2}{*}{ \% Replacement } & \multicolumn{2}{|c|}{ Strength $\left(\mathbf{N} / \mathbf{m m}^{\mathbf{2}}\right)$} \\
\cline { 3 - 4 } & & $\mathbf{7 ~ d a y}$ & $\mathbf{2 8}$ day \\
\hline 1 & 0 & 2.25 & 4.02 \\
\hline 2 & 5 & 3.46 & 4.13 \\
\hline 3 & 10 & 2.10 & 3.92 \\
\hline 4 & 15 & 1.94 & 3.56 \\
\hline
\end{tabular}

Fig1. Compressive Strength at 7 and 28 days

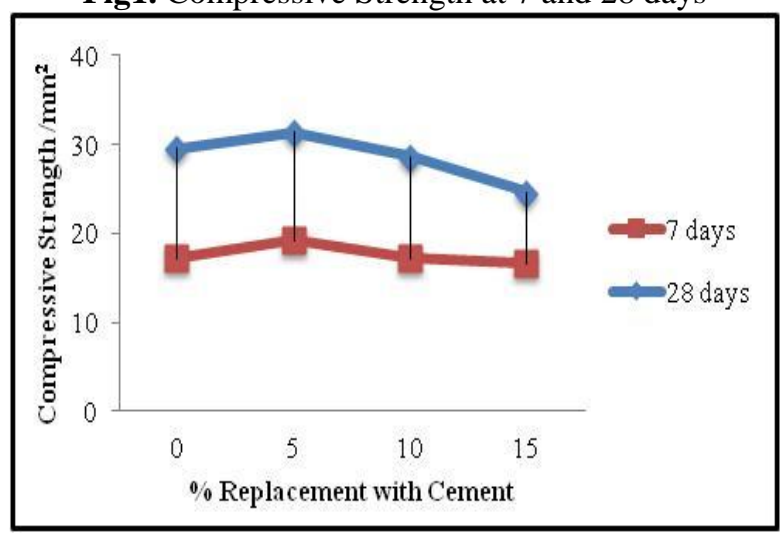

Fig2. Split Tensile Strength at 7 and 28 days

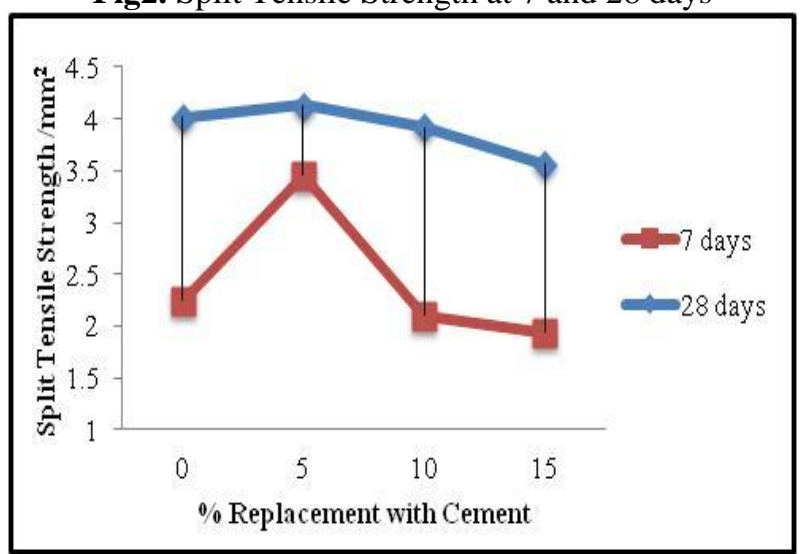




\section{Flexural Strength}

The flexural tensile strength at failure is called modulus of rupture. The knowledge of modulus of rupture is useful in the design of pavement slabs, airfield runways, finding deflection and crack width as flexural

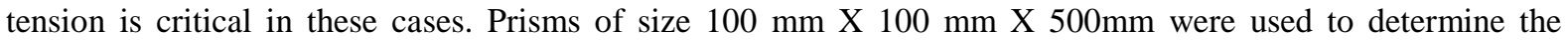
flexural strength. Two point loading was adopted for finding the flexural strength. The specimens were tested in a Flexural Testing Machine.

Table 4: Flexural Strength Result

\begin{tabular}{|c|c|c|c|}
\hline \multirow{2}{*}{ S.No } & \multirow{2}{*}{ \% Replacement } & \multicolumn{2}{|c|}{ Strength (N/mm $\mathbf{2}^{\mathbf{2}}$} \\
\cline { 3 - 4 } & & $\mathbf{7 ~ d a y}$ & $\mathbf{2 8}$ day \\
\hline 1 & 0 & 5.36 & 8.42 \\
\hline 2 & 5 & 6.54 & 8.65 \\
\hline 3 & 10 & 5.46 & 7.54 \\
\hline 4 & 15 & 4.32 & \\
\hline
\end{tabular}

Fig3. Flexural Strength at 7 and 28 days

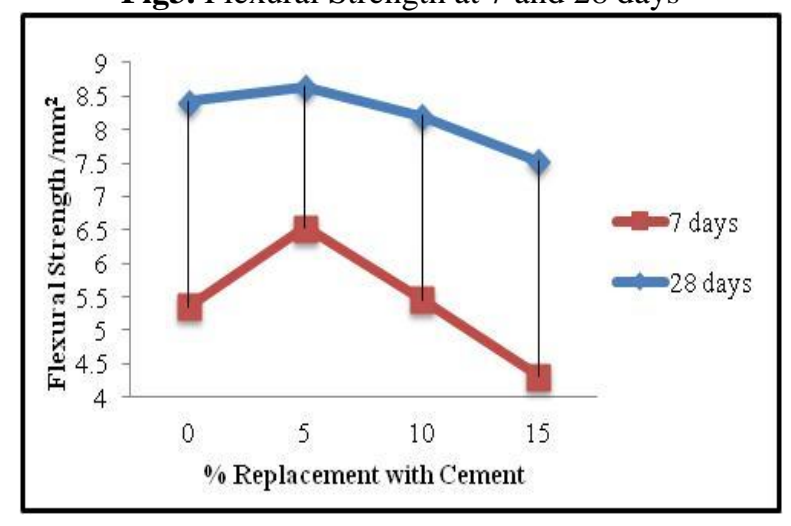

From the tables and figures, it can be seen that dolomite improves the compressive strength, the split tensile strength and the flexural strength of concrete up to certain replacement percentage and then decrease. The maximum compressive and flexural strengths are obtained when the replacement percentage is $5 \%$. The maximum compressive strength obtained at $5 \%$ replacement was found to be $31.35 \mathrm{~N} / \mathrm{mm}^{2}$. The maximum split tensile strength at $5 \%$ replacement was $4.13 \mathrm{~N} / \mathrm{mm}^{2}$. The maximum flexural strength at $5 \%$ replacement was $8.65 \mathrm{~N} / \mathrm{mm}^{2}$.

\section{Conclusion}

Replacement of cement with dolomite powder is found to improve the strength of concrete. The optimal replacement percentage of cement with dolomite powder is found to be $5 \%$ and at this replacement level, the maximum increase in the $28^{\text {th }}$ day compression and flexural strength were found to be $5.84 \%$ and $2.73 \%$ respectively. In case of split tensile strength, the optimal replacement is 5\% and at this replacement level, the percentage increase in split tensile strength was found to be $2.74 \%$.

\section{Reference}

[1]. Piechowka-Mielnik, M., Giergiczny, Z., 2011. Properties of Portland-composite cement with limestone Proceedings of the 13th International Congress on the Chemistry of Cement (13th ICCC), 3-8 July, 2011, Madrid (CD).

[2]. Zotkin, A.G., 2007. Effects of mineral additives in concrete, Journal of Concrete Technology 4, pp. 10-12

[3]. Schone, S., Dienemann, W., Wagner, E., 2011. "Portland dolomite cement as alternative to Portland limestone cement" Proceedings of the $13^{\text {th }}$ International Congress on the Chemistry of Cement (13th ICCC), 3-8 July, 2011, Madrid (CD).

[4]. Henning, O., Kudjakow, A., Winkler, K-G., 1980. Influence of dolomite on the hydration of Portland cement, Scientific Journal of the University of Architecture and Civil Engineering in Weimar 4.

[5]. Salim Barbhuiya, "Effects of fly ash and dolomite powder on the properties of self-compacting concrete", Construction and Building Materials, Volume. 25, 2011, pp.3301-3305

[6]. S. Deepa Balakrishnan., and K. C. Paulose, "Workability and strength characteristics of self compacting concrete containing fly ash and dolomite powder", American Journal of Engineering Research (AJER), Volume. 2, 2013, pp. 43-47

[7]. Kopanitsa, N. O., Anikanova, L. A., Makarevich, M. S., 2002. Fine additives filled with binders based on cement, Journal of Building Materials 9, pp. 2-4. 